\title{
ANALISIS KOMPARASI PROFITABILITAS PERTANIAN PADI ORGANIK DAN ANORGANIK DI DESA LOMBOK KULON KABUPATEN BONDOWOSO
}

\author{
Yeremia von Savigny ${ }^{1}$ \\ Email: yeremiavspasaribu@gmail.com \\ Hari Sukarno 2
}

Novi Puspitasari ${ }^{3}$

\begin{abstract}
Profitability is a very important element for a business or company. Profitability ratios are usually used to see how the effectiveness and efficiency of a business in the use of venture capital. The factors that affect the level of profitability in this study are the cost of production, production, sales and profits. This research discusses how to compare the profitability of organic and inorganic rice farming. The analysis was conducted on 13 samples of organic rice farmers and 30 samples of inorganic farmers domiciled in Lombok Kulon Village, Bondowoso Regency. This study uses two types of profitability, namely Net Profit Margin (NPM) and Return on Capital Employed (ROCE). The test uses the Independent sample t-test and the Mann Whitney Test, depending on the results of the normality test data. The test results show that there are differences in the level of profitability of organic rice farming and inorganic rice farming. The test results with the statistical difference test also showed that there were significant differences in the comparison of the profitability levels in the two agricultural systems. Thus it can be concluded that there are significant differences in the level of profitability of Net Profit Margin (NPM) and Return On Capital Employed (ROCE) in organic and inorganic rice farming systems.
\end{abstract}

Keywords: Profitability Ratio, NPM, ROCE, Organic Rice and AnOrganic Rice.

\footnotetext{
${ }^{1} 1$ Corresponding author: Jurusan Manajemen, Fakultas Ekonomi dan Bisnis, Universitas Jember, Jalan Kalimantan No. 37, Kampus Tegalboto, Kecamatan Sumbersari, Jember, 68121, Jawa Timur, Indonesia.

,2,3 Jurusan Manajemen, Fakultas Ekonomi dan Bisnis, Universitas Jember, Jalan Kalimantan No. 37, Kampus Tegalboto, Kecamatan Sumbersari, Jember, 68121, Jawa Timur, Indonesia.
} 


\section{PENDAHULUAN}

Indonesia merupakan negara dengan iklim tropis dan letak geografis yang sangat baik untuk usaha pertanian. Indonesia terkenal dengan negara yang sangat subur dan memiliki potensi besar dalam bidang pertanian. Setiap tahunnya Indonesia mendapatkan sinar matahari dan curah hujan yang cukup untuk membantu manusia dalam bercocok tanam. Indonesia merupakan negara agraris karena sebagian besar lahannya adalah lahan pertanian, sektor pertanian Indonesia memiliki potensi yang sangat baik karena kesuburan dan sumber daya alam yang sangat melimpah sehingga sangat cocok membangun usaha di bidang agribis.

Sektor pertanian merupakan sektor penting dalam struktur perekonomian Indonesia, dimana sektor pertanian masih menjadi penyerap tenaga kerja terbesar di Indonesia, yaitu sekitar 34,00 persen dan disusul oleh sektor perdagangan sekitar 21,66 persen (BPS, 2014), yang berarti sektor pertanian masih mendominasi struktur tenaga kerja di Indonesia. Menurut (Afifah 2010), sektor pertanian memiliki peranan penting dalam pembangunan perekonomian Indonesia antara lain: (1) sektor pertanian mampu menyediakan kebutuhan pokok yang dibutuhkan oleh masyarakat Indonesia sehingga ketahanan pangan negara dapat terjamin (2) sektor ini dapat menyediakan bahan baku industri (3) menyediakan banyak lapangan pekerjaan (4) sektor pertanian sebagai penyumbang devisa negara.

Menurut data yang ada pada (BPS Statistik Daerah Kabupaten Bondowoso 2016) pada tahun 2015 total luas lahan persawahan yang ada di Indonesia sekitar 8.087.393 hektar, di mana Jawa Timur sebagai salah satu provinsi penyumbang lahan persawahan terluas yang berkisar 1.091 .752 hektar dan disusul oleh provinsi Jawa Tengah seluas 965.262 hektar. Jika dilihat dari hasil produksi padinya, Jawa Timur masih menjadi provinsi dengan produksi tanaman padi tertinggi di Indonesia.

Tabel 1. Provinsi dengan Produksi Padi Tertinggi di Indonesia

\begin{tabular}{cl}
\hline Provinsi & Produksi/ton \\
\hline Jawa Timur & 13.154 .967 \\
\hline Jawa Barat & 11.373 .144 \\
\hline Jawa Tengah & 11.301 .422 \\
\hline Sumber: Badan Pusat Statistik 2015
\end{tabular}

Menurut (Mayrowani 2012), berdasarkan metode budidayanya usahatani padi dibedakan menjadi dua, yaitu usahatani padi organik dan anorganik. Usahatani padi organik atau disebut juga pertanian konvensional adalah usahatani padi yang masih menggunakan bahan-bahan kimia seperti pestisida dan pupuk kimia. Pertanian organik adalah suatu sistem pertanian yang mendukung pertumbuhan biodiversiti atau siklus biologi dan aktivitas biologi di dalam tanah. Sertifikasi dalam pertanian organik sangat penting karena sebagai bukti bahwa pertanian tersebut sudah benar-benar bebas dari bahan kimia.

Kabupaten Bondowoso merupakan daerah agraris sehingga usaha pertanian masih memegang peranan penting dalam sistem perekonomian dan pembangunan. Kabupaten Bondowoso memiliki luas panen tanaman padi yang cukup luas, yaitu 70.796 Ha pada tahun 2015 (BPS Kabupaten Bondowoso, 2016), tetapi dari sekian luasnya lahan sawah, 8 tahun terakhir sebagian lahan sudah dikonversikan dari sistem 
pertanian konvensional ke sistem pertanian padi organik. Salah satu desa yang sangat gencar beralih ke padi organik adalah Desa Lombok Kulon, alasannya adalah semakin menurunnya hasil pertanian karena pertanian terlalu bergantung pada penggunaan pupuk kimia yang berlebihan sehingga merusak struktur tanah.

Menurut penelitian (Hapsari and Aprilia 2010), yang dilakukan didaerah Ngawi tentang usaha tani padi organik didapati produksi rata-rata padi organik lebih rendah dari pada pertanian padi anorganik, yaitu berkisar $5.472,91 \mathrm{~kg} / \mathrm{Ha}$, sedangkan pertanian konvensional $6.399,57 \mathrm{~kg} / \mathrm{Ha}$. Namun demikian pendapatan rata-rata pertanian organik lebih tinggi yaitu sebesar Rp. 5.496.178/Ha, sedangkan pertanian konvensional Rp.3.699.938/Ha. Berbeda dengan penelitian yang dilakukan oleh (Nikolaus 2012) dari hasil penelitiannya rata-rata hasil produksi pertanian organik mencapai $7,400 \mathrm{~kg} / \mathrm{Ha}$, sedangkan rata-rata produksi pertanian anorganik lebih rendah $900 \mathrm{~kg} / \mathrm{Ha}$, yaitu $6.500 \mathrm{~kg} / \mathrm{Ha}$.

Menurut penelitian yang dilakukan (Fauzi 2016), yang diakukan di Desa Rambah Tengah Hilir Kecamatan Rambah Kabupaten Rokan Hulu. Dalam penelitiannya disimpulkan bahwa biaya total rata-rata per hektar per musim tanam yang dikeluarkan petani padi organik sebesar Rp 6.990.441,002, lebih besar dibandingkan petani padi anorganik Rp 5.505.293,183. Namun, nilai jual hasil panen padi organik lebih besar dibandingkan pertanian anorganik. Rata-rata produksi yang diperoleh usaha tani padi organik tiap satu hektar adalah sebesar 4.117,059 kg dengan harga rata- rata tiap kilogram sebesar Rp 7.200. Dengan demikian, diperoleh penerimaan (pendapatan kotor) sebesar $\mathrm{Rp}$ 29.642.823,53, sedangkan rata-rata produksi yang diperoleh usaha tani padi anorganik setiap satu hektar sebesar $3.733,234 \mathrm{~kg}$, dengan harga rata-rata setiap kilogram sebesar Rp 5.500. Sehingga diperoleh penerimaan (pendapatan kotor) sebesar $\mathrm{Rp}$ 20.532.786,07. Dengan demikian, terdapat selisih penerimaan sebesar Rp 9.110.037,46. Terlihat total biaya yang dikeluarkan untuk usaha tani padi anorganik lebih besar dibandingkan biaya yang dikeluarkan untuk usaha tani padi anorganik walaupun selisihnya hanya sebesar Rp 5.505.293,187 per hektar untuk sekali musim tanam. Dari hasi penelitiannya menunjukkan bahwa usaha tani organik dan anorganik sama-sama menguntungkan.

Berdasarkan uraian di atas, ada hal menarik yang perlu untuk dibahas, yaitu mengenai adanya perbedaan perbandingan jumlah produksi dan pendapatan pertanian padi organik dan anorganik pada daerah yang berbeda. Desa Lombok Kulon Kabupaten Bondowoso merupakan desa yang mulai menerapkan sistem pertanian organik dan merupakan daerah yang memiliki potensi unggul untuk menerapkan sistem pertanian organik. Penelitian ini dilakukan untuk mengetahui profitabilitas dari sistem pertanian padi organik dan padi anorganik.

H1: terdapat perbedaan yang signifikan dari tingkat profitabilitas pertanian padi organik dan anorganik di Desa Lombok Kulon Kabupaten Bondowoso.

\section{METODE PENELITIAN}

Penelitian ini menggunakan paradigma positivis, paradigma positivis adalah metode yang digunakan untuk menemukan atau memperoleh konfirmasi tentang hubungan sebab akibat yang biasa dipergunakan untuk memprediksi pola-pola umum suatu gejala sosial atau aktivitas manusia. Paradigma positivis melihat ilmu sosial sebagai metode yang terorganisir untuk mengkombinasikan logika deduktif dengan observasi empiris dari perilaku manusia yang bertujuan untuk mengetahui dan 
mengkonfirmasi hukum kasual yang bisa memprediksi pola umum aktivitas manuisa. (Neuman 2003).

Populasi dalam penelitian ini adalah petani padi organik dan anorganik yang berdomisili di Desa Lombok Kulon dan tergabung dalam kelompok tani. Populasi petani padi di Desa Lombok Kulon Kecamatan Wonosari yaitu 991 orang petani yang terdiri dari 2 jenis budidaya padi, yaitu budidaya padi organik dan petani padi non organik. Petani padi anorganik, yaitu sejumlah 694 orang sedangkan petani padi organik saat ini sejumlah 297 orang. Seluruh petani tersebut tergabung dalam suatu Gabungan Kelompok Tani (GAPOKTAN) yang memiliki 16 kelompok tani. Dari 16 kelompok tani tersebut terdiri dari lima kelompok tani yang anggotanya menerapkan budidaya padi organik dan kelompok tani lainnya yaitu yang anggotanya menerapkan budidaya padi anorganik.

Sampel penelitian dari masing-masing pertanian adalah 13 orang petani padi organik dan 30 orang petani padi anorganik. Kemudian dilakukan wawancara langsung pada setiap petani untuk mendapatkan informasi yang dibutuhkan. Data yang diperoleh akan diolah untuk mengetahui tingkat profitabilitas pertanian padi organik dan anorganik. Tingkat profitabilitas yang diperoleh dari masing-masing sistem pertanian akan dibandingkan secara statistik dengan menggunakan alat bantu analisis SPSS yang kemudian dilihat apakah terdapat perbandingan yang signifikan dari kedua sistem pertanian.

Berdasarkan penyajiannya, penelitian ini merupakan penelitian deskripstif kuantitatif, sedangkan berdasarkan sumbernya, data yang digunakan tergolong data sekunder dan primer yang diperoleh dari wawancara langsung pada sampel petani dan mengakses website Badan Pusat Statistik (BPS) Bondowoso, dan Badan Pusat Statistik (BPS) Jatim dan lainnya. Tingkat profitabilitas dari masing-masih sistem pertanian dihitung menggunakan rumus:

1. Net Profit Margin (NPM)

$\mathrm{NPM}=\frac{\text { Laba Bersih Setelah Pajak }}{\text { Penjualan }} \times 100 \%$

\section{Return on Capital Employed (ROCE)}

$$
\text { ROCE }=\frac{\text { Laba Sebelum Pajak }}{\text { Modal Kerja }} \times 100 \%
$$

Periode pengamatan yang digunakan dalam penelitian ini adalah satu kali musim tanam yaitu dari proses pengolahan lahan hingga panen dan pengangkutan hasil pertanian. Pengujian dilakukan dengan uji beda Independent Sample t-test (statistik parametik berkolerasi) dan uji beda Mann Whitney (statistik non parametik berkolerasi) yang dipilih berdasarkan hasil uji normalitas data.

\section{HASIL DAN PEMBAHASAN}

Penelitian ini dilakukan untuk mengetahui bagaimana perbandingan tingkat profitabilitas pertanian padi organik dan anorganik dan apakah terdapat perbedaan yang signifikan secara statistik. Berdasarkan data yang didapatkan dari hasil survei, 
penelitian ini menggunakan dua metode perhitungan rasio profitabilitas yaitu Net Profit Margin (NPM) dan Return on Capital Employed (ROCE). Pengujian yang telah dilakukan adalah uji beda Independent Sample t-test dan Mann Whitney U-Test, berdasarkan uji normalitas dan uji homogenitas yang telah dilakukan.

Dari tabel 2 dan 3 (apendiks), dapat diketahui rata-rata persentasi profitabilitas yang dihasilkan dari setiap penjualan hasil panen mencapai pertanian padi organik $75,12 \%$. Hasil tersebut tergolong cukup besar yang berarti operasi usaha tani tersebut sangat baik dan mampu menghasilkan laba yang tinggi. Rata-rata profitabilitas Net Profit Margin pertanian padi anorganik mencapai 54,7\%, jumlah tersebut lebih rendah jika dibandingkan profitabilitas sistem pertanian padi organik. Pada tabel 3 dapat diketahui bahwa tingkat profitabilitas Net Profit Margin (NPM) sistem pertanian anorganik tergolong lebih rendah. Hal tersebut cukup menjelaskan bahwa terdapat perbedaan tingkat profitabilitas di antara kedua sistem pertanian. Maka, dapat disimpulkan bahwa tingkat profitabilitas Net Profit Margin pertanian padi organik lebih tinggi daripada Net Profit Margin pertanian anorganik yaitu 75,12\% atau 20,39\% lebih besar dari profitabilitas pertanian padi anorganik. Namun, tujuan utama penelitian ini adalah untuk melihat apakan perbedaan tersebut dapat dikatakan signifikan secara statistik dengan menggunakan uji beda.

Penelitian ini menggunakan dua (2) macam profitabilitas, yaitu profitabilitas Net Profit Margin (NPM) dan profitabilitas Return on Capital Employed (ROCE), maka akan dilakukan juga uji normalitas untuk profitabilitas Return on Capital Employed (ROCE). Berikut adalah tabel hasil uji normalitas untuk profitabilitas Return on Capital Employed (ROCE) untuk pertanian padi organik dan anorganik.

Dari tabel 4 (apendiks) dapat diketahui Profitabilitas Return on Capital Employed (ROCE) pada pertanian padi organik, yang menjelaskan bagaimana tingkat profitabilitas pertanian padi organik berdasarkan modal kerja yang digunakan. Profitabilitas Return on Capital Employed (ROCE) pada pertanian padi organik sangat baik, dimana rata-rata pengembalian modal kerja pada pertanian padi organik mencapai $301,6 \%$ yang berarti tingkat profitabilitas pertanian padi organik tergolong sangat baik jika dilihat dari modal kerja yang digunakan. Tingkat pengembalian modal pada pertanian padi organik sangat baik, dimana semakin tinggi profitabilitas Return on Capital Employed maka efisiensi modal yang digunakan sangat baik.

Dari tabel 5 (apendiks), dapat diketahui profitabilitas Return on Capital Employed (ROCE) pertanian padi anorganik adalah 220,8\%. Jumlah tersebut lebih kecil jika dibandingkan profitabilitas Return on Capital Employed (ROCE) dari pertanian padi organik yaitu 301,6\%, yang berarti efisiensi penggunaan modal dari pertanian padi organik lebih tinggi dengan selisih persentase adalah 80,80\%.

Langkah yang perlu dilakukan sebelum melakukan uji beda yaitu melakukan uji normalitas data. Uji ini dilakukan untuk memastikan sebaran data yang digunakan terdistribusi normal atau justru terdistribusi tidak normal, untuk kemudian digunakan sebagai acuan dalam menentukan uji yang akan digunakan selanjutnya. Uji normalitas data untuk penelitian ini menggunakan uji Shapiro-Wilk dengan alfa sebesar 5\% $(0,05)$. 
Tabel 6. Hasil Uji Normalitas Net Profit Margin (NPM)

\begin{tabular}{ccccc}
\hline \multirow{2}{*}{ Pertanian } & Shapiro-Wilk & \multirow{\alpha}{*}{} & Keterangan \\
\cline { 2 - 2 } & Sig. & & Normal \\
\hline Organik & 0,880 & & 0,05 & Normal \\
An Organik & 0,262 & 0,05 &
\end{tabular}

Sumber : Data sekunder diolah, 2019

Hasil uji normalitas Net Profit Margin (NPM) pada kedua sistem pertanian terdistribusi normal. Hasil uji normalitas data ini menentukan uji beda yang akan digunakan untuk pengujian hipotesis. Uji beda pada profitabilitas NPMmenggunakan Independent Sample t-test. Hasil dari uji beda yang telah dilakukan terangkum dalam tabel 7 berikut.

Tabel 7. Hasil uji beda Independent Sample t-test NPM

\begin{tabular}{cl}
\hline \multicolumn{1}{c}{ Profitabilitas } & \multicolumn{1}{c}{ NPM } \\
\hline Uji Beda & Independent Sample t-test \\
Sig. (2-tailed) & 0,00 \\
Keterangan & Ha diterima \\
\hline Sumber $:$ Data sekunder diolah, 2019
\end{tabular}

Berdasarkan output Independent Sample t-test pada bagian Equal variances Non Assumed diketahui hasil pengujian menunjukkan nilai Sig. (2-tailed) sebesar $0.00<0,05$, maka hasil tersebut dapat digunakan sebagai dasar pengambilan keputusan dalam uji Independent Sample t-test. Berdasarkan hasil sig. (2-tailed) yang lebih kecil dari $\alpha(5 \%)$, maka dapat disimpulkan bahwa Ho ditolak dan Ha diterima, sehingga diketahui bahwa ada perbedaan yang signifikan antara rata-rata profitabilitas petani padi organik dan anorganik berdasarkan data Net Profit Margin (NPM).

Penelitian ini menggunakan dua (2) macam profitabilitas, yaitu profitabilitas Net Profit Margin (NPM) dan profitabilitas Return on Capital Employed (ROCE), maka akan dilakukan juga uji normalitas untuk profitabilitas Return On Capital Employed (ROCE). Berikut adalah tabel hasil uji normalitas untuk profitabilitas Return on Capital Employed (ROCE) untuk pertanian padi organik dan anorganik.

Tabel 8. Hasil Uji Normalitas Return on Capital Employed (ROCE)

\begin{tabular}{cccc}
\hline \multirow{2}{*}{ Pertanian } & Shapiro-Wilk & & \\
& Sig. & A & Keterangan \\
\hline Organik & 1 & & Normal \\
Anorganik & 0,005 & 0,05 & Tidak Normal \\
\hline Sumber : Data sekunder diolah, 2019 & 0,05 &
\end{tabular}


Berdasarkan Tabel 8 dapat dilihat bahwa nilai signifikansi data pertanian adalah 1 , yang berarti lebih besar dari $\alpha(0,05)$, yang berarti data terdistribusi normal. Sedangkan nilai signifikansi untuk pertanian padi anorganik tidak berdistribusi normal dengan nilai signifikansi 0,005 yang berarti lebih kecil dari $\alpha(5 \%)$. Sehingga dapat disimpulkan bahwa uji hipotesis untuk data profitabilitas Return on Capital Employed (ROCE) akan menggunakan uji Mann Whitney U-Test.

Tabel 9. Ranks Uji Mann Whitney Test Data Return on Capital Employed

\begin{tabular}{lcc}
\hline Pertanian & N & Mean Rank \\
\hline Organik & 13 & 29,62 \\
Anorganik & 30 & 18,70 \\
Total & 43 & - \\
\hline
\end{tabular}

Sumber : Data sekunder diolah, 2019

Dari tabel 9 dapat diketahui Mean Rank atau rata-rata peringkat pada setiap kelompok variabel. Kelompok pertama atau kelompok pertanian organik memiliki mean rank sebesar 29,62, sedangkat mean rank untuk sistem pertanian anorganik adalah 18,70. Terdapat perbedaan mean rank pada kedua kelompok variabel, sehingga perlu untuk diketahui apakah perbedaan rata-rata mean rank pada kedua kelompok akan bermakna secara statistik atau yang disebut dengan signifikan. Berikut adalah Tabel 4.23 tes statistik Mann Whitney U-Test untuk melihat bagaimana perbandingan tingkat profitabilitas Return On Capital Employed (ROCE) secara statistik.

Tabel 10. Tes Statistik Uji Mann Whitney Data ROCE

\begin{tabular}{lc}
\hline Profitabilitas & ROCE \\
\hline Mann-Whitney U & 96.000 \\
Wilcoxon W & 561.000 \\
Z & -2.618 \\
Asymp. Sig. (2-tailed) & 0,009 \\
\hline
\end{tabular}

Sumber : Data sekunder diolah, 2019

Tes Statistik uji Mann Whitney Data Return On Capital Employed (ROCE) menunjukkan nilai $U$ sebesar 98 dan nilai W sebesar 561, sehingga bila data dikonversikan ke nilai Z, maka besarnya adalah -2.618 dimana nilai Asymp. Sig. (2tailed) adalah sebesar 0,009. sehingga signifikansi atau P Value $<\alpha 5 \%(0,009<0,05)$. Berdasarkan Asymp. Sig. (2-tailed) atau signifikansi data yang dihasilkan, maka dapat ditarik kesimpulan bahwa Ho ditolak dan Ha diterima atau terdapat perbedaan yang signifikan secara statistik pada perbandingan tingkat profitabilitas Return On Capital Employed (ROCE) pertanian padi organik dan anorganik. 


\section{KESIMPULAN DAN SARAN}

Penelitian ini menguji apakah terdapat perbedaan yang signifikan dari tingkat profitabilitas NPM dan ROCE sistem pertanian padi organik dan anorganik di Desa Lombok Kulon Kabupaten Bondowoso. Penelitian ini menggunakan sampel 13 petani padi organik dan 30 petani anorganik dengan total luas lahan dari masing-masih sampel adalah 6,87 Ha dan 6,86 Ha.

Berdasarkan hasil penelitian pada sub bab sebelumnya, diperoleh kesimpulan penelitian sebagai berikut.

1. Hasil pengujian pada profitabilitas Net Profit Margin (NPM) menunjukkan bahwa terdapat perbedaan yang signifikan antara pertanian padi organik dan anorganik.

2. Hasil pengujian pada profitabilitas Return on Capital Employed (ROCE) menunjukkan bahwa terdapat perbedaan yang signifikan antara pertanian padi organik dan anorganik.

3. Rata-rata persentase tingkat profitabilitas Net Profit Margin (NPM) dari sistem pertanian padi organik adalah $75,2 \%$, berbeda dengan tingkat profitabilitas sistem pertanian anorganik yang lebih rendah yaitu 54,7\%. Sedangkan rata-rata persentase tingkat profitabiltas Return on Capital Employed (ROCE) untuk sistem pertanian organik adalah 301,6\% dan tingkat profitabilitas ROCE sistem pertanian anorganik adalah 220,8\%.

Dengan demikian penelitian ini membuktikan bahwa terdapat perbedaan yang signifikan antara rasio profitabilitas pertanian padi organik dan anorganik berdasarkan NPM dan ROCE, dimana rata-rata tingkat pengembalian atau tingkat profitabilitas sistem pertanian padi organik lebih tinggi dari kedua aspek rasio profitabilitas. Namun tujuan penelitian ini adalah untuk melihat apakah terdapat perbedaan yang signifikan secara statistik atau tidak. Setelah melakukan uji statistik dapat diketahui bahwa terdapat perbedaan yang signifikan dari kedua aspek rasio profitabilitas, artinya Ho ditolak yang artinya terdapat perbedaan yang signigikan dari kedua sistem pertanian.

Berdasarkan hasil penelitian yang dilakukan terkait perbandingan tingkat profitabilitas NPM dan ROCE dari sistem pertanian padi organik dan anorganik di Desa Lombok Kulon Kabupaten Bondowoso, berikut saran yang diberikan oleh peneliti.

1. Untuk penelitian selanjutnya disarankan untuk lebih menggali informasi data penelitian yang lebih terperincI dan lengkap dari petani, yaitu data yang mempengaruhi tingkat profitabilitas dari kedua sistem pertanian.

2. Penelititian selanjutnya diharapkan menambah periode musim tanam dan menggunakan sampel yang lebih besar. Peneliti selanjutnya juga dapat menambahkan rasio profitabilitas yang dapat digunakan dalam penelitian sehingga hasil penelitian yang diperoleh lebih valid untuk mengetahui bagaimana perbandingan tingkat profitabilitas dari kedua sistem pertanian.

3. Penelitian ini adalah penelitian yang bertujuan untuk melihat bagaimana signifikansi perbandingan tingkat profitabilitas pertanian padi organik dan anorganik yang dilihat dari tingkat pengembalian penggunaan modal dan tingkat penjualan. Berdasarkan tujuan utama penelitian dapat pula diketahui bahwa tingkat pengembalian atau 
profitablitas pertanian padi organik lebih tinggi, diharapkan dari penelitian ini para pembaca mendapatkan ilmu yang berguna dan dapat berperan dalam pengembangan sistem pertanian padi organik.

\section{UCAPAN TERIMA KASIH}

Penulis mengucapkan banyak terimakasih kepada responden yaitu petani padi organik dan petani padi anorganik yang berdomisili di Desa Lombok Kulon Kabupaten Bondowoso yang bersedia berpartisipasi dan turut membantu dalam penelitian ini sehingga penelitian ini dapat diselesaikan.

\section{DAFTAR PUSTAKA}

Afifah, D. N. 2010. Peran Sekotor Ekonomi Berbasis Pertanian Terhadap Perekonomian Jawa Tengah Dengan pendekatan Sistem Neraca Sosial Ekonomi (SNSE). Skripsi, Program Studi Ekonomi Pertanian da Sumber Daya, Fakultas Pertanian, IPB.

BPS. Statistik Daerah Kabupaten Bondowoso 2016. Badan Pusat Statistik Kabupaten Bondowoso.

Fauzi. 2016. Analisis Pebandingan Biaya dan Pendapatan Pengunaan pupuk Organik dan Anorganik Pada Usahatani Padi Sawah Irigasi di Desa Rambah Tengah Hilir Kecamatan Rambah Kabupaten Rokan Hulu. Universitas Pasir Panggarian.

Hapsari, dan I. Aprilia. 2010. Analisis Usahatani Padi Sistem Organik Dan Padi Sistem Konvensional (Kajian Pengenmbangan Usaha Tani Padi Organik di Wilayah Kabupaten Ngawi. Malang: Universitas Muhammadiyah.

Mayrowani, H. 2012. Pengembangan Pertanian Organik di Indonesia. Forum Penelitian Agro Ekonomi.

Neuman, W. L. 2003. Social Research Methods Qualitative and Quantitative Approaches. Boston.

Nikolaus. 2012. Analisi Komprasi Usahatani Padi Organik dan Anorganik di Kecamatan Sambirejo Kabupaten Sragen. 24:63-80. 


\section{APENDIKS}

Tabel 2. Tingkat Profitabilitas NPM Pertanian Padi Organik

\begin{tabular}{clcc}
\hline No & Nama & L. Lahan (Ha) & NPM \\
\hline 1 & Mulyono & 0,80 & $80,93 \%$ \\
2 & Mujito & 0,56 & $73,53 \%$ \\
3 & Abdul S & 0,70 & $75,96 \%$ \\
4 & Abdul R & 0,12 & $69,35 \%$ \\
5 & Bari & 0,80 & $75,42 \%$ \\
6 & Khadijah & 0,50 & $73,67 \%$ \\
7 & Ulfa & 0,20 & $63,43 \%$ \\
8 & Ahmadi & 0,35 & $71,51 \%$ \\
9 & Dulwafi & 0,60 & $76,14 \%$ \\
10 & Hendry & 0,60 & $78,15 \%$ \\
11 & Iswandi & 0,50 & $69,71 \%$ \\
12 & Wahyudi & 0,60 & $77,09 \%$ \\
13 & Hos A & 0,60 & $71,01 \%$ \\
\hline
\end{tabular}

Sumber : Data sekunder diolah, 2019 
Tabel 3. Tingkat Profitabilitas NPM Pertanian Padi An Organik

\begin{tabular}{clcc}
\hline No & \multicolumn{1}{c}{ Nama } & L. Lahan (Ha) & NPM \\
\hline 1 & Sadrina & 0,15 & $57,7 \%$ \\
2 & Alvin & 0,55 & $40,9 \%$ \\
3 & Aning & 0,10 & $53,9 \%$ \\
4 & Yakud & 0,10 & $53,1 \%$ \\
5 & Masruroh & 0,15 & $47,0 \%$ \\
6 & Azizah & 0,25 & $47,3 \%$ \\
7 & Niwati & 0,30 & $41,1 \%$ \\
8 & Hodaifah & 0,80 & $46,6 \%$ \\
9 & Pak Basri & 0,20 & $55,7 \%$ \\
10 & Abdul Hadi & 0,20 & $74,0 \%$ \\
11 & Matrasan & 0,20 & $58,8 \%$ \\
12 & Suberi & 0,11 & $53,4 \%$ \\
13 & Akimo & 0,15 & $55,8 \%$ \\
14 & Arip & 0,45 & $28,5 \%$ \\
15 & Syarif & 0,25 & $53,8 \%$ \\
16 & Sa'amo & 0,11 & $54,1 \%$ \\
17 & Pudali & 0,12 & $53,7 \%$ \\
18 & Marzuki & 0,15 & $70,5 \%$ \\
19 & Hasan & 0,20 & $61,6 \%$ \\
20 & Suri & 0,11 & $65,0 \%$ \\
21 & Abdul Bahar & 0,25 & $73,4 \%$ \\
22 & Hasan Kur & 0,15 & $73,8 \%$ \\
23 & Asla & 0,30 & $61,8 \%$ \\
24 & Mustofa & 0,25 & $66,4 \%$ \\
25 & Pahol & 0,15 & $50,9 \%$ \\
26 & Muhammad & 0,10 & $55,2 \%$ \\
27 & Abdullah & 0,20 & $50,4 \%$ \\
28 & Musnadin & 0,15 & $57,4 \%$ \\
29 & Harini & 0,35 & $28,6 \%$ \\
30 & Abdul H & 0.31 & $36,8 \%$ \\
\hline & Jumlah & $\mathbf{6 , 8 6}$ & -10 \\
\hline & Rata-rata & & $\mathbf{0 , 2 2}$ \\
\hline
\end{tabular}

Sumber : Data sekunder diolah, 2019 
Tabel 4. Tingkat Profitabilitas ROCE Pertanian Padi Organik

\begin{tabular}{llcc}
\hline No & Nama & Luas Lahan (Ha) & ROCE \\
\hline 1 & Mulyono & 0,80 & $416,2 \%$ \\
2 & Mujito & 0,56 & $275 \%$ \\
3 & Abdul S & 0,70 & $316,9 \%$ \\
4 & Abdul R & 0,12 & $220,7 \%$ \\
5 & Bari & 0,80 & $308,2 \%$ \\
6 & Khadijah & 0,50 & $281,2 \%$ \\
7 & Ulfa & 0,20 & $174,3 \%$ \\
8 & Ahmadi & 0,35 & $252,5 \%$ \\
9 & Dulwafi & 0,60 & $317,9 \%$ \\
10 & Hendry & 0,60 & $359,2 \%$ \\
11 & Iswandi & 0,50 & $231 \%$ \\
12 & Wahyudi & 0,60 & $338,1 \%$ \\
13 & Hos A & 0,60 & $246,0 \%$ \\
\hline
\end{tabular}

Sumber : Data sekunder diolah, 2019 
Tabel 5. Tingkat Profitabilitas ROCE Pertanian Padi Organik

\begin{tabular}{|c|c|c|c|}
\hline No & Nama & Luas Lahan (Ha & ROCE \\
\hline 1 & Sadrina & 0,15 & $235,3 \%$ \\
\hline 2 & Alvin & 0,55 & $169,5 \%$ \\
\hline 3 & Aning & 0,10 & $216,1 \%$ \\
\hline 4 & Yakud & 0,10 & $211,3 \%$ \\
\hline 5 & Masruroh & 0,15 & $185,9 \%$ \\
\hline 6 & Azizah & 0,25 & $189,6 \%$ \\
\hline 7 & Niwati & 0,30 & $169,8 \%$ \\
\hline 8 & Hodaifah & 0,80 & $187,1 \%$ \\
\hline 9 & Pak Basri & 0,20 & $223,6 \%$ \\
\hline 10 & Abdul H & 0,20 & $382,5 \%$ \\
\hline 11 & Matrasan & 0,20 & $241,8 \%$ \\
\hline 12 & Suberi & 0,11 & $214,0 \%$ \\
\hline 13 & Akimo & 0,15 & $223,8 \%$ \\
\hline 14 & Arip & 0,45 & $139,4 \%$ \\
\hline 15 & Syarif & 0,25 & $215,1 \%$ \\
\hline 16 & Sa'amo & 0,11 & $220,4 \%$ \\
\hline 17 & Pudali & 0,12 & $214,7 \%$ \\
\hline 18 & Marzuki & 0,15 & $335,1 \%$ \\
\hline 19 & Hasan & 0,20 & $258,4 \%$ \\
\hline 20 & Suri & 0,11 & $284,6 \%$ \\
\hline 21 & Abdul B & 0,25 & $376,5 \%$ \\
\hline 22 & Hasan K & 0,15 & $382,5 \%$ \\
\hline 23 & Asla & 0,30 & $263,1 \%$ \\
\hline 24 & Mustofa & 0,25 & $298,6 \%$ \\
\hline 25 & Pahol & 0,15 & $204,7 \%$ \\
\hline 26 & P. Muh & 0,10 & $230,9 \%$ \\
\hline 27 & Abdullah & 0,20 & $200,3 \%$ \\
\hline 28 & P.Mus & 0,15 & $235,0 \%$ \\
\hline 29 & Harini & 0,35 & $141,0 \%$ \\
\hline \multirow[t]{3}{*}{30} & Abdul H & 0.31 & $160,4 \%$ \\
\hline & Jumlah & 6,86 & - \\
\hline & Rata-rata & 0,22 & $220,8 \%$ \\
\hline
\end{tabular}

Sumber : Data sekunder diolah, 2019 